\title{
Validation of accelerometer-based energy expenditure equations using doubly-labelled water technique in 11-13 year-old Sri Lankan children
}

\author{
Prasangi M Dabare ${ }^{1}$, Pujitha Wickramasinghe ${ }^{2}$, Indu Waidyatilaka ${ }^{3}$, Sarita Devi ${ }^{4}$, Anura V Kurpad ${ }^{5}$, D \\ Samaranayake, Maduka de Lanerolle-Dias", Rajitha Wickremasinghe ${ }^{8}$, Andrew P Hills ${ }^{9}$, ${ }^{*}$ Pulani \\ Lanerolle $^{10}$
}

Sri Lanka Journal of Child Health, 2021; 50(4): 637-643

DOI: http://doi.org/10.4038/sljch.v50i4.9853

\begin{abstract}
Introduction: Accelerometer based prediction equations are used to calculate physical activity energy expenditure (PAEE) among children. Currently, accelerometer-derived PAEE prediction equations validated against a criterion method do not exist for Sri Lankan children.
\end{abstract}

Objective: To assess the validity of published prediction equations to estimate PAEE in Sri Lankan children against the doubly labelled water (DLW) technique.

${ }^{1}$ Lecturer, Dept. of Physiotherapy, Faculty of Allied Health Sciences, General Sir John Kotelawala Defence University, Sri Lanka, ${ }^{2}$ Senior Professor, Dept. of Pediatrics, Faculty of Medicine (F/M), University of Colombo, Sri Lanka, ${ }^{3}$ Senior Lecturer, Dept. of Biochemistry \& Molecular Biology, F/M, University of Colombo, Sri Lanka, ${ }^{4}$ Lecturer, St. John's Research Institute, St. John's National Academy of Health Sciences, Bangalore, Karnataka, India, ${ }^{5}$ Professor, St. John's Medical College, St. John's National Academy of Health Sciences, Bangalore, Karnataka, India, ${ }^{6}$ Senior Lecturer, Dept. of Community Medicine, F/M, University of Colombo, Sri Lanka, ${ }^{7}$ Senior Lecturer, Dept. of Biochemistry \& Molecular Biology, F/M, University of Colombo, Sri Lanka, ${ }^{8}$ Professor, Dept. of Public Health, F/M, University of Kelaniya, Sri Lanka, ${ }^{9}$ Professor, School of Health Sciences, College of Health \& Medicine, University of Tasmania, Australia, ${ }^{10}$ Professor, Dept. of Biochemistry \& Molecular Biology, FM, University of Colombo, Sri Lanka

*Correspondence: pulani@bmb.cmb.ac.lk

(iD https://orcid.org/0000-0002-1204-3740

(Received on 10 October 2020: Accepted after revision on 24 November 2020)

The authors declare that there are no conflicts of interest.

Funding: The International Atomic Energy Agency, Vienna donated the stable isotopes, laboratory equipment and consumables through a Technical Cooperation project (project number SRL/06/035). Open Access Article published under the Creative Commons Attribution CC-BY (C) (i) License
Method: Ninety-six children aged 11-13 years from an urban area of Sri Lanka were included in the study. Energy expenditure was assessed using the DLW technique over 10 days and participants wore ActiGraph accelerometers during the same period. Correlation between the measured and predicted PAEE was assessed by the Pearson correlation coefficient. Validity of equations was assessed by the paired t-test and the level of agreement using the Bland Altman analysis.

Results: Predicted PAEE values were significantly $(p<0.05)$ correlated with the measured PAEE except for the equations of Treuth and Schmitz. Prediction equations of Ekelund, Freedson, Mattock and Zhu significantly overestimated measured PAEE $(\mathrm{p}<0.05)$ whereas, Trost and Puyau equations significantly underestimated PAEE. A wide limit of agreement with a large mean bias was observed in all estimated PAEE, except for the equation of $\mathrm{Zhu}$.

Conclusions: Existing accelerometer-based PAEE equations have low accuracy in predicting PAEE in Sri Lankan children.

(Key words: Adolescents, Accelerometers, Physical activity energy expenditure, Stable isotopes)

\section{Introduction}

Accelerometers are motion sensor devices used to assess physical activity based on movement counts in different populations. They provide information on movement by converting the raw acceleration data into activity counts at a pre-determined frequency and time period. There are many different models of accelerometers available commercially and the ActiGraph ${ }^{\text {wGT3 }} \mathrm{x}-\mathrm{BT}^{\circledR}$ triaxial accelerometer used in the current study is commonly used to assess physical activity among children ${ }^{1}$.

Despite the numerous advantages of accelerometers in quantifying movement and predicting energy expenditure, there is lack of evidence on validated methods to calculate energy expenditure using raw accelerometer counts in different populations ${ }^{2}$. Regression analysis has been used in many studies to estimate total energy expenditure (TEE) and physical activity energy expenditure (PAEE) from raw accelerometer data ${ }^{3-5}$. These equations have been validated against the gold standard methods 
including indirect calorimetry and doubly labelled water (DLW) method.

Though several prediction equations have been developed to calculate energy expenditure among children, there is a lack of consensus on the best regression equation to predict energy expenditure accurately in young people $\mathrm{e}^{5-9}$. Also, the ability of these equations to estimate the energy expenditure of activities of daily living in Sri Lankan children is uncertain. The majority of published energy expenditure equations have been constructed based on vertical activity counts. However, triaxial accelerometers are comparatively more subtle in capturing the torsional movements frequently involved in physical activities performed by children $^{10-12}$. There is a paucity of data and there is no published regression equation using accelerometry to predict energy expenditure in Sri Lankan children.

\section{Objectives}

To assess the validity of the published prediction equations to estimate the PAEE against DLW as the criterion technique in 11-13 year-old children from an urban area of Sri Lanka.

\section{Method}

Study participants and study design: The total sample consisted of 96 children (47 girls and 49 boys) aged 11-13 years attending two schools in the Colombo Municipal Council area. Sixteen girls and boys were consecutively recruited from each grade of each school to represent the national distribution of nutritional status ${ }^{13}$.

\section{Anthropometric measurements}

A calibrated electronic scale (Seca $803^{\circledR}$ by SECA GmbH \& Co. Kg., Hamburg, Germany) was used to measure the weights of the participants with a precision of $0.1 \mathrm{~kg}$. Height was measured using a stadiometer (Seca $225^{\circledR}$ by SECA GmbH \& Co. Kg., Hamburg, Germany) to the nearest $0.1 \mathrm{~cm}$.

\section{DLW technique for the calculation of body} composition, TEE and PAEE

A weighed mixture of $0.12 \mathrm{~g} . \mathrm{kg}^{-1}$ body water of $99.8 \%{ }^{2} \mathrm{H}_{2} \mathrm{O}$ and $1.8 \mathrm{~g} . \mathrm{kg}^{-1}$ body water of $10 \% \mathrm{H}_{2}{ }^{18} \mathrm{O}$ (Sigma-Aldrich Co, 3050, Spruce street, ST. Louis, USA) was used to prepare the DLW dose ${ }^{14}$. Given that the dose is prescribed per unit total body water (TBW), the TBW was estimated using the validated equation for Sri Lankan adolescents ${ }^{15}$.

On day 1, a baseline urine sample was first collected. DLW dose was then administered to the participants and the dosing time was recorded. Participants consumed the dose through a straw and $50 \mathrm{~mL}$ of drinking water was added to the same dose bottle and participants were asked to consume the rinsed water to ensure that they completely ingested the dose. A second urine sample was collected 4 hours after administration of the dose. On day 10, the final urine sample was collected. All samples were stored at $-20{ }^{\circ} \mathrm{C}$ prior to analysis.

Urine samples were analysed for isotopic enrichments of ${ }^{2} \mathrm{H}$ and ${ }^{18} \mathrm{O}$ in duplicates using isotope-ratio mass spectrometer (IRMS, Delta V Advantage, ThermoScientific, Bremen, Germany) at the Mass Spectrometry Laboratory, St. John's Research Institute, Bangalore, India. Fat-free mass (FFM) was estimated from the TBW corrected for the non-aqueous hydrogen exchange and the age and gender specific hydration coefficient ${ }^{14,16}$. Fat mass (FM) was calculated by subtracting FFM from the body weight. The rate of $\mathrm{CO}_{2}$ production was calculated by the difference in the ${ }^{2} \mathrm{H}$ and ${ }^{18} \mathrm{O}$ turnover rates using the equation of Schoeller et $\mathrm{al}^{17}$. This was corrected for the non-aqueous isotope exchange and the total energy expenditure (TEE $\left.\mathrm{DLW}_{\mathrm{DL}}\right)$ was calculated using the modified Weir equation ${ }^{18}$, assuming an average food quotient of 0.86 . The PAEE $_{\text {DLW }}$ was calculated from the TEE $\mathrm{DLW}_{\text {as }} 0.9$ $\mathrm{TEE}_{\mathrm{DLW}}$ - basal metabolic rate $(\mathrm{BMR})^{3,11}$ assuming $10 \%$ of TEE would be the thermic effect of food $(\mathrm{TEF})^{19}$. The prediction equation of Schofield was used to calculate the $\mathrm{BMR}^{20}$.

\section{Accelerometer}

ActiGraph wGT3x-BT ${ }^{\circledR}$ triaxial accelerometers (Pensacola, FL, USA) were used and participants were requested to wear the device around the waist with the unit positioned over the right hip for the same 10 days duration of the DLW assessment. Participants were instructed to remove the device during sleep and all water-based activities. On day 10 , the investigator collected the accelerometers.

Data were downloaded and analysed using Actilife software $^{\circledR}$, version 6 (Pensacola, FL, USA). Time durations of 60 minutes or more of continuous zeros, allowing for 2 minutes of non-zero intervals were considered as non-wear time and were excluded from the analysis ${ }^{21}$. Days were considered as valid if at least 600 minutes of wear time was noted during wake time $^{21}$. Data were included in the analysis if the participants completed a minimum of three such valid week-days and one valid weekend day ${ }^{21,22}$.

\section{Energy expenditure calculation using prediction equations}

Energy expenditure was calculated using eight regression equations. A summary of these equations is provided in Table 1 . 
Table 1

Summary of published child specific energy expenditure prediction equations for ActiGraph accelerometers

\begin{tabular}{|c|c|c|c|c|}
\hline Reference & Sample & Criterion method & Activities & Equation \\
\hline Trost et al & $\mathrm{n}=30($ Boys $=19$, Girls $=11)$ & Indirect calorimeter & $\begin{array}{l}\text { Treadmill walking, } \\
\text { jogging }\end{array}$ & $\begin{array}{l}\mathrm{EE}=0.0008 \mathrm{cpm}+0.08 \\
\text { weight }-2.23\end{array}$ \\
\hline Ekelund $e t a l^{3}$ & $\mathrm{n}=26($ Boys $=15$, Girls $=11)$ & DLW technique & Free living activities & $\begin{array}{l}\mathrm{AEE}=1.042 \mathrm{cpm}-243.4 \\
\text { gender }+238\end{array}$ \\
\hline Puyau et $a l^{4}$ & $\mathrm{n}=26($ Boys $=14$, Girls $=12)$ & Whole room calorimeter & $\begin{array}{l}\text { Free living activities } \\
\text { Treadmill activities } \\
\text { Over ground activities }\end{array}$ & $\begin{array}{l}\mathrm{AEE}=0.0183+ \\
0.00001 \mathrm{cpm}\end{array}$ \\
\hline Treuth $e t a l^{7}$ & $\mathrm{n}=74$ (Girls only) & Indirect calorimeter & $\begin{array}{l}\text { Free living activities } \\
\text { Walking, running }\end{array}$ & $\begin{array}{l}\text { METs }=2.01+ \\
0.000856 \mathrm{cpm}\end{array}$ \\
\hline Schmitz et $a l^{9}$ & $\mathrm{n}=74$ (Girls only & Indirect calorimeter & $\begin{array}{l}\text { Free living activities } \\
\text { Walking, running }\end{array}$ & $\begin{array}{l}\mathrm{EE}=7.6628+0.1462 \\
([\mathrm{cpm}-3,000] / 100)+ \\
0.2371 \times \text { x weight }-0.00216 \\
([\mathrm{cpm}-3,000] / 100)^{2}+ \\
0.004077([\mathrm{cpm}-3,000] / \\
100 \times \text { weight })\end{array}$ \\
\hline Freedson et $a l^{5}$ & $\mathrm{n}=80$ (Boys and girls) & Indirect calorimeter & $\begin{array}{l}\text { Treadmill walking, } \\
\text { running }\end{array}$ & $\begin{array}{l}\text { METs }=2.757+(0.0015 \times \\
\text { cpm })-(0.08957 \times \text { age })- \\
(0.000038 \times \text { cpm } \times \text { age })\end{array}$ \\
\hline Mattock et $a l^{8}$ & $\mathrm{n}=246($ Boys $=110$, Girls $=136)$ & Indirect calorimeter & $\begin{array}{l}\text { Sitting, lying, } \\
\text { hopscotch, walking, } \\
\text { jogging }\end{array}$ & $\begin{array}{l}\mathrm{EE}=-0.933+ \\
0.000098 \mathrm{cpm}+0.091 \mathrm{age} \\
-0.0422 \mathrm{gender}\end{array}$ \\
\hline
\end{tabular}

All energy expenditure values were converted to $\mathrm{kcal} /$ day to aid in comparisons with each equation and with the criterion DLW technique. The MET values were converted into $\mathrm{kcal} /$ day by multiplying with the conversion factor assuming $4.825 \mathrm{kcal} / \mathrm{L}$ of oxygen was consumed ${ }^{18}$. When TEE was the outcome, predicted BMR was subtracted from 0.9 TEE to calculate the PAEE assuming $10 \%$ of TEE was the $\mathrm{TEF}^{19}$.

Ethical issues: Study protocol was approved by the Ethics Review Committee of the Faculty of Medicine, University of Colombo, Sri Lanka (EC/16/192). All participants were recruited after obtaining informed written consent from parents and assent from children and those with no acute/chronic illness.

Statistical analysis: The results reported here included a final sample of 79 children. One participant was excluded due to incomplete urine sample collection for the DLW protocol and another four participants since their post-dose urine sample enrichments were lower for ${ }^{2} \mathrm{H}$ and ${ }^{18} \mathrm{O}$ as measured by IRMS. A further four participants were excluded as the minimum accelerometer wear-time was not completed. Results of another eight participants were removed from the analysis since those values were identified as outliers $( \pm 3$ standard deviations (SD) from mean in each data column $)^{23}$. SPSS Statistical software version 21.0 was used to analyse the data. Skewness and histograms were used to assess the normality of data. PAEE calculated from each equation was compared with the PAEE from the DLW-reference method (PAEE $\mathrm{DLW}_{\mathrm{D}}$ ) using the Pearson's rank correlation coefficient and the paired sample t test was used to assess over or underestimation of PAEE by the equations. The Bland-Altman technique was used to assess the agreement of PAEE estimated from DLW method with the PAEE calculated ${ }^{24}$. In this method, the differences between the PAEE DLW $_{\text {and estimated }}$ PAEE (y-axis) were plotted against the average of PAEE $_{\text {DLW }}$ and estimated PAEE (x-axis). Level of statistical significance for all tests was set at $\mathrm{p}<0.05$.

\section{Results}

Age and basic anthropometric parameters of the population are presented in Table 2. Only height was significantly higher $(\mathrm{p}<0.05)$ among girls compared to boys.

Table 2: Age and basic anthropometric parameters of the population by gender

\begin{tabular}{|l|c|c|c|}
\hline \multirow{2}{*}{ Characteristic } & Total $(\boldsymbol{n}=\mathbf{7 9})$ & Girls $(\boldsymbol{n}=\mathbf{3 8})$ & Boys $(\boldsymbol{n}=\mathbf{4 1})$ \\
\cline { 2 - 4 } & Mean $\mathbf{\text { SD }}$ & Mean \pm SD & Mean \pm SD \\
\hline Age (years) & $12.0 \pm 0.81$ & $12.1 \pm 0.8$ & $12.0 \pm 0.8$ \\
\hline Weight $(\mathrm{kg})$ & $35.23 \pm 7.67$ & $35.84 \pm 8.28$ & $34.66 \pm 7.12$ \\
\hline Height $(\mathrm{m}) *$ & $1.45 \pm 0.07$ & $1.47 \pm 0.08$ & $1.43 \pm 0.06$ \\
\hline Body mass index $\left(\mathrm{kgm}^{-2}\right)$ & $16.66 \pm 2.62$ & $16.51 \pm 2.51$ & $16.8 \pm 2.67$ \\
\hline Fat-free mass $(\mathrm{kg})$ & $25.13 \pm 4.64$ & $24.79 \pm 5.07$ & $25.45 \pm 4.23$ \\
\hline Fat mass $(\mathrm{kg})$ & $10.1 \pm 4.86$ & $11.05( \pm 5.0)$ & $9.22 \pm 4.62$ \\
\hline
\end{tabular}

$p<0.05^{*}$, girls vs. boys (Independent sample t-test) 
When accelerometer derived values were compared between girls and boys, counts per minute (cpm) were significantly higher among the boys $(\mathrm{p}<0.05)$. The mean PAEE ${ }_{\text {DLW }}$ of the total sample was 513.4 $( \pm 344.3) \mathrm{kcal} /$ day and was higher among the boys compared to the girls $(582.7 \pm 370.6 \mathrm{kcal} /$ day vs. $438.6 \pm 300.6 \mathrm{kcal} /$ day) yet this difference was not statistically significant ( $\mathrm{p}>0.05)$.
The mean PAEE calculated using the reference DLW technique and the estimated using the prediction equations are shown in the Table 3 . All the estimated PAEE values were significantly correlated $(p<0.05)$ with the measured energy expenditure value except the values estimated using Treuth $\mathrm{M}$, et $a l^{7}(\mathrm{p}=0.05)$ and Schmitz $\mathrm{KH}$, et $a l^{9}$ $(p=0.09)$ equations (Table 3$)$.

Table 3: Physical activity energy expenditure (PAEE) estimates using selected prediction equations

\begin{tabular}{|l|c|c|c|c|}
\hline \multicolumn{1}{|c|}{ Reference } & $\begin{array}{c}\text { Mean PAEE } \pm \text { SD } \\
\text { (kcal/day) }\end{array}$ & $\begin{array}{c}\text { Bias } \pm \text { SD } \\
\text { (kcal/day) }\end{array}$ & $\begin{array}{c}\text { Pearson correlation } \\
\text { coefficient(r) }\end{array}$ & $\begin{array}{c}\text { 95\% confidence } \\
\text { interval }\end{array}$ \\
\hline PAEE $_{\text {DLW }}$ & $513.4 \pm 344.3$ & - & - & - \\
\hline Trost et al $^{2}$ & $216.3 \pm 134.8$ & $297.1 \pm 397.4^{*}$ & $0.23^{* *}$ & 208.1 to 386.2 \\
\hline Ekelund et al $^{3}$ & $713.6 \pm 197.9$ & $-200.2 \pm 332.5^{*}$ & $0.35^{* *}$ & -274.7 to -125.8 \\
\hline Puyau et al $^{4}$ & $222.6 \pm 112.4$ & $290.8 \pm 315.7^{*}$ & $0.41^{* *}$ & 220.1 to 361.5 \\
\hline Treuth et al $^{7}$ & $976.2 \pm 493.6$ & $-462.8 \pm 535.0^{*}$ & 0.22 & -582.6 to -343.0 \\
\hline Schmitz et al $^{9}$ & $1017.9 \pm 464.5$ & $-504.5 \pm 423.8^{*}$ & 0.19 & -921.8 to -687.2 \\
\hline Freedson et al $^{5}$ & $944.5 \pm 509.3$ & $-431.1 \pm 540.8^{*}$ & $0.24^{* *}$ & -552.3 to -310.0 \\
\hline Mattock et al $^{8}$ & $836.6 \pm 395.4$ & $-323.2 \pm 416.5^{*}$ & $0.37^{* *}$ & -416.5 to -229.9 \\
\hline
\end{tabular}

The limits of agreement between the energy expenditure estimated from the criterion method with those from the prediction equations were assessed using the Bland-Altman analysis (Figure 1A-F).
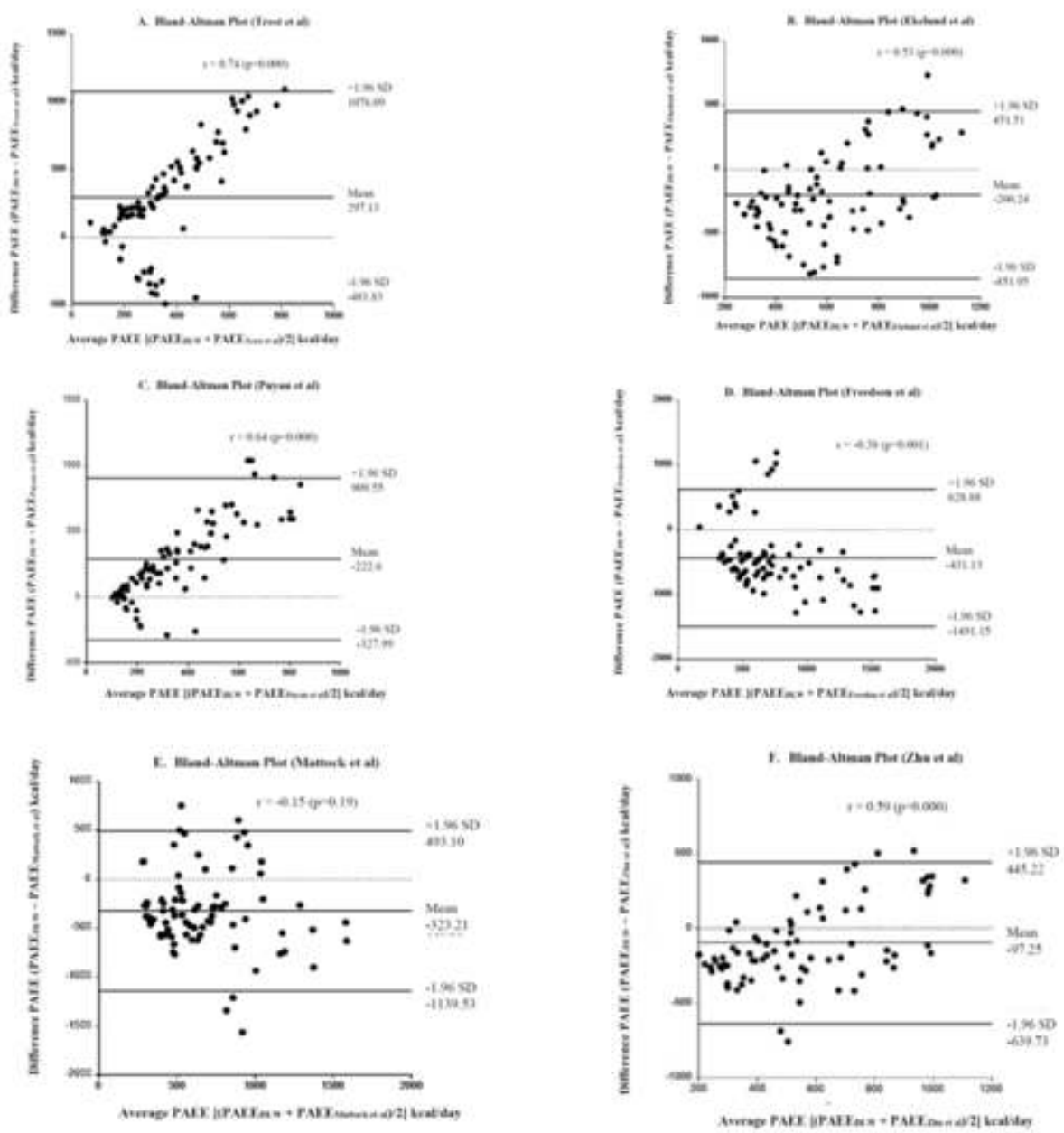

Figure 1 (A-F): Bland-Altman plots showing bias between the PAEE calculated using DLW method aod estimated using the prediction equations against the average of PAEE measured and estimated 
Significant correlations were observed between the average and difference of PAEE DLW $_{\text {and PAEE }}$ estimated by all equations $(\mathrm{p}<0.05)$ except Mattocks $\mathrm{C}$, et $a l^{8}$ demonstrating a systematic bias. Further, Bland Altman plots indicated relatively large mean bias with wide limits of agreements with all equations. Prediction equations of Ekelund ULF, et $a l^{3}$, Freedson $\mathrm{P}$, et $a l^{5}$, Mattocks $\mathrm{C}$, et $a l^{8}$ and Zhu Z, et $a l^{6}$ significantly overestimated the measured energy expenditure whereas, the prediction equations of Trost SG, et $a l^{10}$ and Puyau MR, et $a l^{4}$ equations significantly underestimated it among the study population.

\section{Discussion}

Reliable and valid physical activity and energy expenditure measurements among children are essential to identify problems with energy balance and to assess the effectiveness of interventions to promote physical activity and to reduce sedentary behaviour. Pearson's correlation coefficient was used as a simple measure of association between the PAEE predicted using the existing equations with the criterion method. Six out of eight equations showed a significant correlation coefficient. However, the correlation coefficient values ranged from low to moderate values $(0.23-0.55)$. This means that only $5.3 \%$ to $30.3 \%$ of variation in the actual energy expenditure was explained by the existing equations. Therefore, the Bland-Altman technique was used to further clarify this agreement or non-agreement of PAEE estimated from DLW method with the PAEE calculated. In this method also, the differences and averages between the PAEE calculated using the criterion method and estimated using equations were significantly correlated demonstrating a systematic bias $(\mathrm{p}<0.05)$ with a relatively large mean bias with wide limits of agreements with all equations thus confirming a poor validity.

The energy expenditure estimates by the equations of Treuth $\mathrm{M}$, et $a l^{7}$ and Schmitz $\mathrm{KH}$, et al ${ }^{9}$ were not significantly correlated with the mean $\mathrm{PAEE}_{\mathrm{DLw}}$ and the mean bias was larger compared to the other estimates. However, both equations were developed using adolescent girls $(n=74)$ and it is likely to affect accuracy when used among both boys and girls. As expected, the energy expenditure estimated using the equation of $\mathrm{Zhu} \mathrm{Z}$, et $a l^{6}$ was significantly $(\mathrm{p}<0.05)$ correlated $(\mathrm{r}=0.55)$ with the criterion method with minimal bias $(-97.25 \mathrm{kcal} / \text { day })^{6}$. They used cpm based on the vector magnitude, which represents all three axes whereas, all the other equations included the cpm only based on the vertical axis. The current study also used the activity counts based on the vector magnitude and this may be the reason for the equation of $\mathrm{Zhu} \mathrm{Z}$, et $a l^{6}$ to be more accurate in predicting energy expenditure of Sri Lankan children.
The energy expenditure values estimated from all the equations were substantially different from each other and from the energy expenditure measured using the criterion method. Similar validation studies are also in agreement with the results of this study ${ }^{6,11}$. Though we did not observe a particular pattern in the discrepancy of energy expenditure values estimated using prediction equations, it may have been caused by the characteristics of the participants in the development studies including age, anthropometric parameters; criterion methods used, choice of activity types used and processing of raw accelerometer counts. The studies by Trost SG, et $a l^{10}$ and Freedson $\mathrm{P}$, et $a l^{5}$ developed their equations using only treadmill-based activities ${ }^{8,10}$. Activities that children normally perform are complex and diverse and the poor agreement may have been due to the fact that these activities were not considered by these reported equations. Poor validity of using laboratory-derived equations to measure the energy expenditure among free-living children have been highlighted in other studies ${ }^{3,11}$. The equation by Ekelund ULF, et $a l^{3}$ was expected to estimate energy expenditure accurately since it is the only study which used free-living activities performed over 14 days against the DLW technique. Comparatively, a lower positive bias was noted in energy expenditure prediction $(-200.24 \mathrm{kcal} /$ day $)$ but with a wide limit of agreement $((-851.95)$ $451.51 \mathrm{kcal} /$ day); this equation was developed in a relatively small sample size $(n=26)^{3}$.

The key strength of this study is that to the best of our knowledge, this is the first study to assess the validity of existing published regression equations to predict energy expenditure using the accelerometer data against the criterion DLW technique in a large sample of Sri Lankan children. We used estimated BMR to calculate the PAEE from the $\mathrm{TEE}^{22}$. However, the BMR prediction equation has not been validated for the Sri Lankan setting; thus it is likely to introduce a systematic bias to the energy expenditure calculations. Therefore, in future studies, integrating BMR assessment methods will improve the accuracy of the prediction of energy expenditure.

\section{Conclusions}

The existing regression equations to predict energy expenditure using accelerometer data were not able to accurately estimate energy expenditure among free-living Sri Lankan children.

\section{Acknowledgements}

We thank all the children and their parents for participation in the study and the IAEA for funding (Technical Cooperation project SRL/06/035). 


\section{References}

1. Sutherland R, Campbell E, Lubans DR, Morgan $\mathrm{PJ}$, Okely $\mathrm{AD}$, Nathan $\mathrm{N}$, et al. "Physical activity 4 everyone" school-based intervention to prevent decline in adolescent physical activity levels: 12 month (mid-intervention) report on a cluster randomised trial. British Journal of Sports Medicine 2016; 50(8): 48895.

https://doi.org/10.1136/bjsports-2014-094523

PMid: 26359346 PMCid: PMC4853531

2. Strong WB, Malina RM, Blimkie CJR, Daniels SR, Dishman RK, Gutin B, et al. Evidence based physical activity for school-age youth. Journal of Pediatrics 2005; 146(6): 732-7. https://doi.org/10.1016/j.jpeds.2005.01.055 PMid: 15973308

3. Ekelund ULF, Sjöström M, Yngve A, Poortvliet E, Nilsson A, Froberg K, et al. Physical activity assessed by activity monitor and DLW in children. Medicine and Science in Sports and Exercise 2001; 33(2): 275-81. https://doi.org/10.1097/00005768-20010200000017

PMid: 11224818

4. Puyau MR, Adolph AL, Vohra FA, Butte NF, Maurice R, Adolph AL, et al. Validation and calibration of physical activity monitors in children. Obesity Research 2002; 10(3):150-7. https://doi.org/10.1038/oby.2002.24

PMid: 11886937

5. Freedson P, Pober D, Janz KF. Calibration of accelerometer output for children. Medicine and Science in Sports and Exercise 2005; 37(11): 523-30.

https://doi.org/10.1249/01.mss.0000185658.28 284.ba

PMid: 16294115

6. Zhu Z, Chen P, Zhuang J. Predicting Chinese children and youth' $s$ energy expenditure using actigraph accelerometers: a calibration and cross-validation study. Research Quarterly for Exercise and Sport 2013; 84(sup2): 56-63. https://doi.org/10.1080/02701367.2013.850989 PMid: 24527567

7. Treuth M, Schmitz K, Catellier D., McMurray $\mathrm{R}$, Murray D, Almeida $\mathrm{M}$, et al. Defining accelerometer thresholds for activty intensities in adolescent girls. Medicine and Science in Sports and Exercise 2004; 36(7): 1259-66.

8. Mattocks C, Leary SAM, Ness A, Deere K, Saunders J, Tilling K, et al. Calibration of an accelerometer during free-living activities in children. International Journal of Pediatrics and Obesity 2007; 2(4): 218-26.

https://doi.org/10.1080/17477160701408809

PMid: 17852552

9. Schmitz KH, Treuth M, Hannan P, Ring KB, Catellier D, Pate R. Predicting energy expenditure from accelerometry counts in adolescent girls. Medicine and Science in Sports and Exercise 2005; 37(1): 155-61. http://doi.org/10.1249/01.MSS.0000150084.97 823.F7

PMid: 15632682 PMCid: PMC2491725

10. Trost SG, Ward DS, Moorehead SM, Watson PD, Riner W, Burke JR. Validity of the CSA activity monitor in children. Medicine and Science in Sports and Exercise 1998; 30(4): 629-33.

https://doi.org/10.1097/00005768-19980400000023

PMid: 9565947

11. Nilsson A, Brage S, Riddoch C, Anderssen SA, Sardinha LB, Wedderkopp N, et al. Comparison of equations for predicting energy expenditure from accelerometer counts in children. Scandinavian Journal of Medicine and Science in Sport 2008; 18(5): 643-50. https://doi.org/10.1111/j.16000838.2007.0069 4.x

PMid: 18208433

12. Alhassan S, Lyden K, Howe C, Kozey S, Nwaokelemeh O, Freedson PS. Accuracy of accelerometer regression models in predicting energy expenditure and METs in children and youth. Pediatric Exercise Science 2012; 24(4): 519-536

https://doi.org/10.1123/pes.24.4.519

PMid: 23196761 PMCid: PMC4005275

13. Jayatissa R, Gunathilaka M, Fernando D. National nutrition and micronutrient survey 2012 part I: Anaemia among children aged 6-59 months and nutritional status of children and adults. Available from:

file://C:/Users/Windows\%20User/Downloads/ Sri_Lanka_National_Nutrition_and_Micronutr ient_Survey_2012.pd $\mathrm{d} f$

14. Assessment of body composition and total energy expenditure in humans using stable isotope technique. Vol. 3, IAEA Human Health Series. 2009.

15. Wickramasinghe VP, Lamabadusuriya SP, Cleghorn GJ, Davies PS. Development of height-weight based equation for assessment of body composition in Sri Lankan children. 
Indian Journal of Pediatrics 2010; 77(2): 15560.

https://doi.org/10.1007/s12098-009-0333-5

PMid: 20101480

16. Lohman TG, Ring K, Pfeiffer K, Camhi S, Arredondo E, Pratt C, et al. Relationships among fitness, body composition, and physical activity. Medicine and Science in Sports and Exercise 2008; 40(6):1163 70.

https://doi.org/10.1249/MSS.0b013e318165c8 $6 \mathrm{~b}$

PMid: 18460987 PMCid: PMC2561299

17. Schoeller DA, Ravussin E, Schutz Y, Acheson KJ, Baertschi P, Jéquier E. Energy expenditure by doubly labeled water: validation in humans and proposed calculation. American Journal of Physiology 1986; 250(5): R823-30. https://doi.org/10.1152/ajpregu.1986.250.5.R8 23

PMid: 3085521

18. Weir JB. New methods for calculating metabolic rate with special reference to protein metabolism. Journal of Physiology 1949; 109:1-9.

https://doi.org/10.1113/jphysiol.1949.sp00436 3

PMid:15394301 PMCid:PMC1392602

19. Poehlman ET, Horton ES. The impact of food intake and exercise on energy expenditure. Nutrition Reviews 1989; 47(5): 129-37. https://doi.org/10.1111/j.17534887.1989.tb028 17.x

PMid: 2654774
20. Schofield WN. Predicting BMR, new standards and review of previous work. Human Nutrition. Clinical Nutrition 1985; 39(Suppl. 1): 5- 41.

21. Jemaa HB, Mankai A, Mahjoub F, Kortobi B, Khlifi S, Draoui J, et al. Physical activity level assessed by accelerometer and PAQ-C in Tunisian children. Annals of Nutrition and Metabolism 2018; 73(3): 234-40. https://doi.org/10.1159/000492673 PMid: 30227412

22. Yildirim M, Verloigne M, Bourdeaudhuij I De, Androutsos O, Manios Y, Fels R. Study protocol of physical activity and sedentary behaviour measurement among schoolchildren by accelerometry - Cross-sectional survey as part of the ENERGY-project. BMC Public Health 2011; 11(1): 182.

https://doi.org/10.1186/1471-2458-11-182

PMid: 21439040 PMCid: PMC3078096

23. Kannan KS, Raj SS. Outlier labeling methods for medical data. In: logistics, supply chain and financial predictive analytics 2019. Springer, Singapore. https://doi.org/10.1007/978-981-13$0872-7 \quad 6$

https://doi.org/10.1007/978-981-13-0872-7_6

PMid: 30427567

24. Bland JM, Altman D. Statistical methods for assessing agreement between two methods of clinical measurement. The Lancet. 1986; 327(8476):307-10. https://doi.org/10.1016/S0140-6736(86)908378 